\title{
BLOOD GASES, ACID-BASE BALANCE AND SERUM ELECTROLYTES CHANGES IN PNEUMONIC BUFFALO-CALVES
}

\author{
Kamel, A. A. and Hoda, M. L. Abd-Alla \\ Anlmal Health Research Institule, Zagazig, Egypl
}

\begin{abstract}
The selected animals jor the present study were 80 buffalo-calves of both sexes. $4-8$ months old. These calves were subjected to carejul clinical examulations. Go calves showed the clinical sings of pneumonia, while the rest, 20 colves were clinically healthy. The preseni investgation almed to study the extent of changes in blood gases, aciatbuse bolance and serum electrolyte values in association with pheumonta in buf. falo-calves. Blaod gas tensions, acid-base measurenemts and serum eleatrolyte concenfrations were deternined in 10 pneumonic calses (distased group) conpared will/ cor responding values of 10 healthy calves (control group). Blood gas artalysls reveated significant decrease (P<0.01) in both blood $\mathrm{pH}$ and axygen tension ( $\mathrm{PO}_{2}$ ) while carbon dioxdele tension ( $\left(\mathrm{PWO}_{2}\right.$ ) showed significant decrease (P<O.OH). Bicartonatc ( $\mathrm{HCO}_{3}$ ) lev els; total carbon diaxde $\left(\mathrm{TO}_{2}\right)$ and base kxcess $(\mathrm{BE})$ in pneumanic calves, were insigriflcantly affected and stul within the nonnal physiological levels. Stgnificand inicreasic $(P<0.05)$ in potassum levels with significant decrease (P<0.05] in chloride levels were detected in diseased buffalocabes. The oblained data reveated that pneumonia in calves was assaclated with disonders in blood gases, acid-base balkuce and elecirolyle values and that analysis of blood gases and actd-base status is very useful in evaluat ing the diagrasis and prognosis of prewnonia in calves.
\end{abstract}

\section{INTRODUCTION}

Respiratory affectlons particularly pneumonlia are confcred to be major problens annong bufFalo-calves, caustng scvere economic losscs through rcductuon of weight gain. high morbidity and mertally rates (Abd El-Ghani et al., 1990; Youssef et al., 1992 and Barrett, 1998). Thicsc ulifections are a complex interactous betwcen baetertal, viral infextion and enviromumental stressors (Howard, 1086). Pasteurclla spp. Coryncbacterfum pyogens as well is Staph. aurcus, strept.

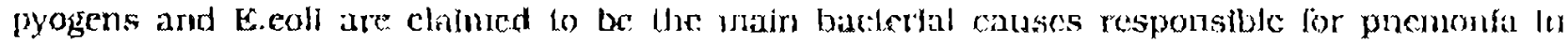

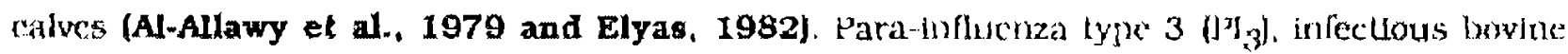

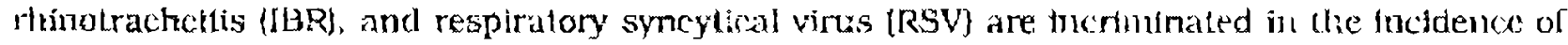


cnzootic pneumonic (PIrie et al., 1981). Envirommental conditions spcclally cold, damp weather. amonia, overcrowding, poor ventilation as wcll as poor hygicnlc measures play a role in predisposing of outbrcaks of rcsplratory diseases (Woldehlwet et al., 1990).

Balance of blood ases and acid-base status are critical physiological criteria for the maintenance of nornal function. Blood gas analysis is onc of the most important aids th the diagriosis and prognosis of respiratory complication (El-Sebaic et al., 1987 and Abd El-Raof and Hassan, 1999). Acid-base balance of the body IuJds is important because the chemieal reactions of the body being controlled by enzymes are very greally infuenced by the changes in pH (Tasker, 1969). When the $\mathrm{pH}$ changes, nonnal metabolle reactions are altered and boty processes are impalred. Scrious disorders of acid-base balance occur in several clinical disorders in caltle, sheep and goats (Huls, 1974).

Respiratory systent play an important role in regulation of acid-base balanec and blood gases through the ellmination of carbon dloxdde through the ventilation process (Coles, 1986 and Bouda and Jagos, 1991).

Electrolytes and acid-base balance arc interrclated in the body in that the vartous anions and cations participate in physioehemical butfcring of body lluids against sudden changes in blood pH (Simmons, 1962 and Gingerich, 1981). Evaluation of clectrolyte levcls and aeid-barse parameters of pationt provide necessary information hat wlll lead to greater unclorstanding of the nature of disease process and guidc line to the way of therapy (Brobest, 1975 and Robert et al., 1990).

The purpose of this Investigallon was to study the extent of changes in blood gases, acid-base balance and serum electrolytes values in association with pneurnonia in bulfalo-calves.

\section{MATERIAL AND METHODS}

The sclectrol animals for thc prescnl study were 80 buffalo-calves, $4-8$ months old and af both sexes, relatcd to a private farm in Sharkia Govcrnorals. Clinical signs of pneumonta wcre observed and recorded in 60 calves, whilc the rest. 20 buffalo calves were ellnleally healthy under the same cnvironmental and managemental condilions. The laboratory study was carried out on 10 calvcs alfected with pneurnonla compared with 10 clinlcally heallhy ones.

From each animal 2 nil sanple of jugular venous bloud was collected anaerobically into syn ringe whose dead space had prewously flled with $1 / 1000$ sodiun heparn. These samples were immedialely placed on icc-bath and processed within one hour of collechon. Blond gases measurements werc performed using Coming pLL-Lluod gas analyser Model 168. The analyser directiy 


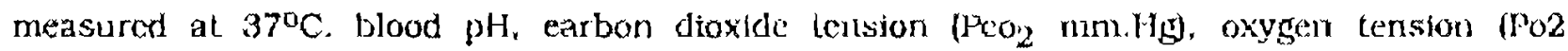
mn. Hg). Bicarbonate $\left(\mathrm{Hco}_{3}{ }^{-} \mathrm{mmol} / \mathrm{L}\right)$, total carbon dloxide $\left(\mathrm{lco}_{2} \mathrm{mmol} / \mathrm{L}\right)$ and base exccss (BE mmolfl) wore calculated automatieally by the same apparatus.

Another bluod sample (5 ml) was collected form cach antmal for obtaining clear sera for the deternination of scrum electrolyte concentralions. Blood serum sodium and potassium lcyds wcre detcrmined using flame pholometer (Corning Modei 410) as described by Oser (1979). Scrum chloride level was delemined accurding to Freid (1972). The obtained data were stalisticaliy aralyscd according to Snedecor and Cochran (1982).

\section{RESULTS}

The most prominent elinical signs of pneumonta in affected calves were mucoid nasal disclarge, cough, anorcxiat, congestod mucous membrantes, alcceleruted respiration. Auscultiation revealed shnorrital chest sounds.

Rresultis of the determinations of pH, blood gascs and acid-base paramele is were illuslialcal in Table (1). Mcan levels of blowd serum electrolytes ill both healthy and pneumunc buffalo ralve's werc prescrited in liable (2).

\section{DISCUSSION}

Resplratory discases constilule a major causc of morbidity and mortaitly in fecdtol calde. Preumonia and ouher respiratury tract infections were incrinirated to be the principic causes of all call death in 41 as of the herds (Hassan, 1987 and Sayed, 1988). Baclerla, viruses and fungI are the main causcs of such diseascs. The poor hygiente enwronmental conditions play an important role as predisposing factors that assist in the prevalence of diseased condttions (Bryson et al., 1978).

Close observation concerning clinical signs revealcx mucoid hasal discharge, colugh, anorexla. congested mucous membrancs, acceleraled respiration and abnomíl lung sounds on auscullation at different areas of the lungs in the diseased buffald-calves. These findings wre sirnilar Lo those recorded by Youssef et al. (1992); El-Sheikh et al, (199a) and Abd El-Raol and Has$\operatorname{san}(199 \theta)$.

The respiratory system has a role in the regulation of acid-base balance alud this by removal of carbon dloxide from the bloud and reduce the concentration of tarbonie arld in the blood (Donawiek and Beave, 1968 und Carlson, 1997).

Diseases whel are diredly or indirectly aflect the functions of the resplratory system aiter the actd-base and electrolyte expuibisrium of the body. Fncumenia inierfere with matn function of 
the lung mexhianisin and eonsequently increase in recention of $\mathrm{CO}_{2}$ in blood which transfoumed into carboulc acid resulting in resplratory acldosis (Carlson, 1997 and Abd EI-Raof and Has. san, 1999].

In this invesugation, the results of blood $\mathrm{pH}$, bloox gases and acld-base status in buffalocalves with pneunonia (Table 1) were slgniffcant decreased (P<0.01) in both blood $\mathrm{pH}$ and oxygen tension $\left(\mathrm{PO}_{2}\right)$. while significant tricrease $(\mathrm{P}<0.01)$ in carbon dioxide tension $\left(\mathrm{Pco}_{2}\right)$ was rccorded wher compared with those healthy ones, Bicarbonate $\left(\mathrm{HCO}_{3}\right)$. tolal $\mathrm{CO}_{2}\left(\mathrm{TCO}_{2}\right)$ and base excess (BE) values were insignificantly affected but still within the normal physjological levels. These findings are in close agreement with those reportcd by Troussef, 1984: Verhoeff et al., 1985; Linden et al., 1995 and Nagy et al., 1998).

Changes in blood gas values In calves suffering from pneumonia rovealed that a condition of hypoxia was generally noticed among affected calves together with hypercapnia. The low values of Pon could be attributed to disturbances of blood oxygenation process in pncunoniar as a re sult of resplratory discases (LInden et a1., 1995). From the phystological mcchanisms known to causc hypoxia: hypoventilation or breathing air (or a gas inixture) with a low $\mathrm{PO}_{2}$ (Hinstaw and Murray, 1980). Hypercapnia has only one clinically important causc of alveolar hypowentilition (Hinshaw and Murray, 1880). Hypoventiletion occurs when not enough (resh air is breathed Into alveolar spaces to raise the pulmonary capillary $\mathrm{PO}_{2}$ to normal levels and to allow carbon dyoxide to leave the blood stream (Verhoeff al., 1985). Durng hypovenulation, the $\mathrm{PO}_{2}$ must decrease and the $\mathrm{PcO}_{2}$ must increase (Hinshow and Murray. 1980).

The fall in blood $\mathrm{pH}$ in the pneumonk calves was due to the hypovenulation and interference with gascous excbange (Reynoids. 1963). Respiralory acidosis was observel in diseascd calves (lowered vahes of $\mathrm{pH}$ and increased $\mathrm{PoO}_{2}$ valucs). This alteration could be attributed to deereased pulmonary ventilation and retenion of cxcess of $\mathrm{CO}_{2}$ in blood associated with pneumomia (Coles, 1986 and El-Sebale et al., 1987). In pneumonia and bronchitis there was a marked Inerease in $\mathrm{PCO}_{2}$ values in blood associated with dropping of blood $\mathrm{pH}$ values (Alpern, 1967 and Brohest. 1975). The authors dcclared that such alteration mainly duc to interference in the gaseous exchange and retained carbon dloxide.

Respiratory acilosis aceurs as result of failure of the lungs to cxcrete $\mathrm{CO}_{2}$. The conlinuing production of $\mathrm{Co}_{2}$ from tussue metabolism results in Increased plasma carbon diuxdde and carbonic acid and the latter was ionized to produce an increased hydrogen fon concentration to wards acidic medium and conscquently a lall in blood pH (Brobest, 1975). In a trial of the body to relict the accumulation of acids in the blood, the $\mathrm{H}^{+}$entcrs the cell and the intracellular $\mathrm{K}$ ions conc out, wheb explains the increases obscrved in scrum potassium (Coles, 1986). The 
non significant change in $\mathrm{Hco}_{3}^{-}$valucs Indicated mctabolic compcnsation. Rounghton (1964) added that the respiratory aeidosis usually accompanicd with partial compensation and consequently increase in blood $\mathrm{Hco}_{3}$ ".

Regarding the rcsults of electrolytes values (Table 2), serum sodium levels showcd insignificant decrcase. Serum potasslusm values were signiffantly increased $(P<0.05)$, whlie serum chloride kvels werc slgnifeantly decreased (P<0.05) in pneumonic calves when compared witl the healthy ones. These results werc similar to those rcported by EL-Bheikh et al. (1094); Abd ElRaof and Hassan (1990) and El-sebaje et al. (2002). The inercase of scrum polassium levels may be related to the accumulation of acids $\left(\mathrm{H}^{+}\right)$in the blood. the $\mathrm{H}^{+}$inters the cell and (lie intraecllular $\mathrm{K}^{+}$fons come out IColes, 1986). The fall in scrum chloride levels could be due to increased blood bicarbonate ( $\mathrm{HCO}_{\mathrm{g}}{ }^{-}$) (Rounghton, 1964).

It was concluded that, pneumonia has a great infuence on $\mathrm{pH}, \mathrm{PO}_{2}$ and $\mathrm{PcO}_{2}$ values resulcing in hypoxia and respiratory actosis and analysis of block gases and actl-base status is very use ful in evaluating the diagnusis and prognosfs in some diseases sucl pneumonta in calves. 
Table (1): Blood gases and acid-base balance values in both clinically healthy and pneumonic buttalo-calves.

\begin{tabular}{|c|c|c|c|c|}
\hline \multirow{2}{*}{ Variable } & \multicolumn{2}{|c|}{ Healtby buffalo-calves } & \multicolumn{2}{|c|}{ Pneumonic buffalo-calves } \\
\hline & Mean \pm S.E & Range & XIean \pm S.E & Range \\
\hline $\mathrm{pH}$ & $7.346 \pm 0.014$ & $7.286-7.412$ & $7.278 \pm 0.012^{\mathrm{m}}$ & $7.235 \times 7.356$ \\
\hline $\mathrm{PCO}_{2}(\mathrm{~mm} \cdot \mathrm{Hg})$ & $46.25 \pm 1.40$ & $39.9-52.9$ & $55.73 \pm 2.28 \mathrm{mo}$ & $44.7-65.3$ \\
\hline $\mathrm{Po}_{2}(\mathrm{~mm} \cdot \mathrm{Hg})$ & $56.03=1.74$ & $47,6-62.3$ & $48.14 \pm 1.92$ & $+2.2-59.3$ \\
\hline $\mathrm{Hco}_{3}(\mathrm{mmol} / \mathrm{L})$ & $24.20 \pm 1.13$ & 17.9 .28 .5 & $26.57 \pm 1.04$ & 21.6 .32 .5 \\
\hline$I_{c o}(\mathrm{mmol} / \mathrm{L})$ & $29.10 \pm 0.90$ & $24.3-33.2$ & $30.30 \pm 1.00$ & $25.4-35.2$ \\
\hline BE $(\mathrm{mmol} / \mathrm{L})$ & $-0.980 \pm 0.08$ & $.7 .5-(4.3)$ & $-1.080 \pm 0.10$ & $.6 .3-(3.6)$ \\
\hline
\end{tabular}

Table (2): Serum electrolytes values in both clinically bealthy and pneumonic burfalo-calves.

\begin{tabular}{|c|c|c|c|c|}
\hline \multirow{2}{*}{ Variable } & \multicolumn{2}{|c|}{ Healthy buffalo-calves } & \multicolumn{2}{|c|}{ Pneumonic buffalo-calves } \\
\hline & Mean \pm S.E & Range & Mean \pm S.E & Range \\
\hline $\begin{array}{l}\text { Sodium } \\
\text { (mmollt) }\end{array}$ & $134.60 \pm 2.24$ & $123-145$ & $129.80 \pm 1.01$ & $124-134$ \\
\hline $\begin{array}{l}\text { Potassium } \\
\text { (mmoltu) }\end{array}$ & $5.19 \pm 0.10$ & $4.71-5.72$ & $6.07 \pm 0.31^{*}$ & $5.22-6.83$ \\
\hline $\begin{array}{l}\text { Chloride } \\
\text { (mmovL) }\end{array}$ & $102.10 \pm 2.33$ & 93.115 & $92.10 \pm 2.67 *$ & $81-107$ \\
\hline
\end{tabular}




\section{REFERENCES}

Abdel-Ghanl, M.; El-Seedy, F. R.; Shokry, S. and Rida, E. M. (1990) : Incidence and bacterial causes of buffalo-calves mortality with respiratory disorders. Vet. Med. J.. Giza, 38 (2): 233.

AbdeI Raof, Y. M. and Hassan, H. Y. (1999) : Ultrasonography and other atds for calf pneumonla diagnosts. $5^{\text {th }}$ Sci. Cong. Egyptian Society for Cattle Diseases, Asslut. Egypt.

Al-Allawy, T. A; Mottelib, A. A: Nashid, S. M. and Salem, H. (1979) : A study on pneunonit in buffalo-ealyes in Egypt. J. of Egyptiar Vet. Med. Assoc.. 39 (2): 2328.

Alpern, D. (1967) : Pathologic physiology. P. 153-155. MIr Publichers, Moscow.

Barrett, D. C. (1998) : Bovine Resplratory Diseases. A clnician's perspertive. Caule Praclice. B: $251-255$.

Bouda, J, and Jagos, P. (1991) : Disorders in the acid-basc balance. In.: Vragula, L.. cel. Mctabolic disorders and their prevention In Sarm antrnals. Amsterdan: El-Sevicr, P. 248268.

Brobest, D. (1975) : Evaluation of elinical disorders of aeid-base balance, J. Am. Vel. Med. Ass.. 166 (4): $355-364$.

Bryzon, D. C.: McFerran, J. B.; Ball, H. J. and Nelll, S, D. (1978) : Observatious on outbreak of resplatory discase in housed calves (1) Eplderntological, chemical and milcrobiologi cal (nndings. Vet. Rec., 103 (1) : 485-509.

Carlson, G. P. (1997) : Fluid, Electrolyte and Actd-base balance. In: Kancko. J.J.: Harvey. J.W. and Bruss, M.L. Cds. Clitical Blochemlstry of Domesuc Anlmais. $5^{\text {th }}$ Ed. San Diego: Academic Press, 485.516.

Colet, E. H. (1986) : A 'Tcxtbook of Veternary Clinical Pathology. $4^{\text {th }}$ ed. W.B. Saunders Co., Phisladelphta. London, Toronto. P. 220-260.

Donawick, W. $J_{v}$ and Bane, A E. (1968) : Blood gases, Acld-base balance and Alveolar-Arterial Oxygen Gradient In Calves. Arr. J. Vet. Res. 29 (3): $561-567$.

El-Sebale, A: Amer, A, Nafie, E.; Abd E1-Ail, Th. And Sadiek, A. H. (1987): Cliricul. haematological and acid-base changes accompanylng some resplratory and alimentary manifestations among fattening buffalo-calves, Asslut Vet. Med. J. 19 (37): 147-154.

El-Sebate, A. H.; All, A. A. and Sadiek, A. H. (2002) : Bronchopnemonla in buffalo-cillves in Asslut Governorate: II-Studies on changes of acid-base balance. elextrolytes and some antioxidants assuciated with the disease. Asslut Vet. Med. J. 46 (92): 156-168. 
El-Shefkh, A. R.; Mohga Abd E1-Razek; Egmat, M. and Asma, A A (1994): Cilnical, biochcmical and baeteriological studies on respiratory affections in buffalo-calves. $2^{\text {nd }}$ Vet. Med. Cong, Zagazig University, P. 646-657.

Elyas, A. H. (1982) : Mycological and Bactertological studies on the causes of pneumoniat altecting burfalo-calves. Ph. D. Thesls. Fae. Vet. Med. Assilut University.

Freid R. (1972) : Determination of blood scrum etilonide. J. Clin. Chem. Blochem., 10: 280.

Gingerich, D. A (1981) : Fluid, Shock and Blood Therapy. "In current veterinary cherapy". Food Animal Practice. P. 17-27 Edited by Howard and W.C. and McMullan Saunders Company. Philadelphia-London. Toronto.

Hastan, A (1987) : Cuntcal and some btochemical blood changes accompanylng allmentary and respiratory manilestation anuong lallening burfalo-calves. M.V.Se. Thesis, fiae. Vel. Med. Assiut Uniy.

HIlls, G. (1974)! "Acid-Lasc balanee". Chemistry, Phystology and Pathophysiology, Williams \& WilkIns Company. Baltimore. $3^{\text {rd }}$ Ed.

Hlashaw, H. C. and Murray, J. F. (1980) : Discases of the chest. Phitadelphla, W.b. Salunders (Cited by Verhoct et al. 1985). Vet. Rec. 117:202.204.

Howard, J. L. (1986) : Current veterlnary thcrapy, Cood animal practice. W.B. Saundcrs Company. Phyladelphta. U.S.A.

Linden, A.; Desmecht, D.; Amary, H.; Daube-G.; Lecomte, S. and Lekeux, P. (1995) : Pulmonary vertilation mechanics. gas exchange and hacuodynamics in calves following Intratracheal inoculation of Pasteurclla haemulytica, Zenualbl Veterinar Med. Assoc., 42: $531-544$.

Nagy, O.: Michna, A; Kovac, G,; Seldel, H. and Paullkova, I. (1998) : The effect of respiratory diseases in calves on the blood gas values and aeld-base balance Vetcrnaml Mcdicina. 43 (3): $69-74$.

Oser, B. L. (1979) : Hawk's physiological ehemistry. 14 th Ed. McGraw-Hill Book Company Ltd., London.

Pirie, H. M.: Pringle, C. D.; Allan, E. M, and Kennedy, G. J. (1981) : Acute [atal pneumonla in calves due to respiratory syncytial virus. Vet. Rec., 104:411-416.

Reynolds, E. O. R. (1963) : Brit. Med. J. 1192 (Chted by Verhueff el al., 1985). Vet. Rec. 117: $202-204$

Robert, W.; Bunnett, Ellzabethlee-Lewandrowskj and Ent Lewandrowski (1990) : Elcctrolyte. 
aeid-base balance. In Textbook of Clinical Laboratory Mediclne. Edited by MeClalchey. D.K. $1^{\text {st }}$ Ed.. William and Wikins-Blatimore. Philadelplula, Hong Kong London, Munich. Sydney. Tokoys. P. $331-354$.

Rounghtan, Fx J. W. [1964) : Transport of oxygen and carbon dioxide in Handbook of Physiology, 1. respiration Sec. 2. P. 767-829. Ediled by Fenm, W.O. and Rahn, H.; Amertean Physiologiral Soclety, Washington.

Sayed, A M. (1988) : Clinieal and some blood trace elements changes following respiratory and allmertary distubances among calves, M.V.Sc. Thesis. Fac. of Ved. Med., Assiut Univ.

Simmons, D. H. (1962) : Clinlcal disorders of Ruld and clecholyte molabolism. Megraw-Hill Book Company, INC. New York, Toronto and London.

Snedecor, G. W. and Cochran, W. C. (1982) : Statistlcal Melhod. $7^{\text {th }}$ Ed. Jowa Stalc Uniw. Press, Ames, lowa, USA.

Tasker, J. B. (1969) : Fluid, Electrolytes and acid-base abnomalities In cattic. J.A.V. Med. Ass., 155 (12): 1906 1909.

Verhoef, J.: Wherda, A: Van Nieuwstadt, A. P. and Bultelaar, J. W. (1985): Spontaneous bovine respiratory syncylal virus Infections in calves: Arterial blood gas. pH and bicarbonate values. Vet. Rec., 31:202-204.

Woldehivet, z.; Mamache, B. and Rowan, T. G. (1990) : The eflects of age, environmental temperature and relatuc humidity on the bactcrial hora of the upper respiratory traet in calves. Br. Vet. J., 145: 211-218.

Youssef. M. A. (1984) : Respiratory diseases arising from atr pollution Inside sheep pens and methods of treatment and prophylaxis of these diseases. PH. D. Thesis Fac. Vct. Med. Zagazigg University.

Youssef, M. A.; Waffaa, M.: Abd El-Razek; Hamad, A. El-Sadawy and Abdella, M. Scleirn (1992) : Clinical and laboratory studies on an outbrak of bactcrial resplratory broubles in buflalo-calves in Egypt. Proc. $5^{\text {th }}$ Scl. Cong. Fac. Vet. Med. Assiul Univ. 92-103. 
الملنئص العيبي

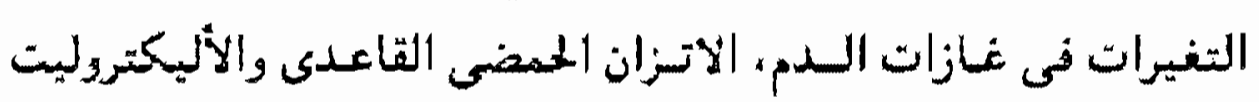

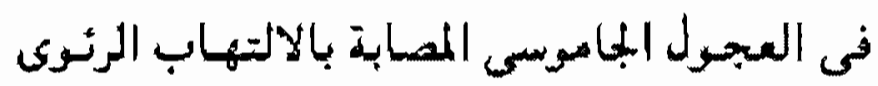

عادل علمى كامل - هدى مسحمد لطفى عبد الله

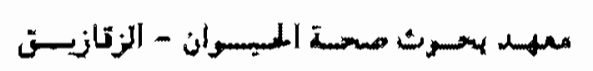

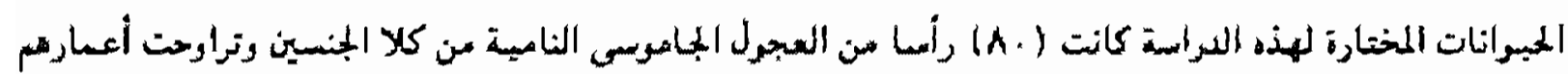

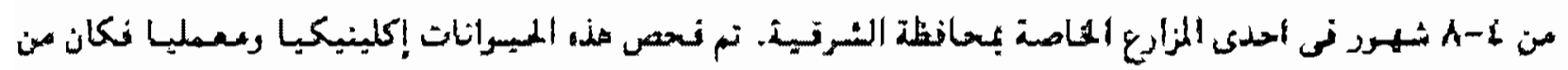

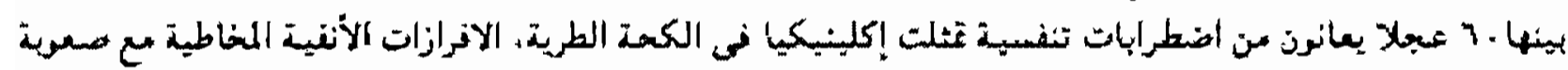

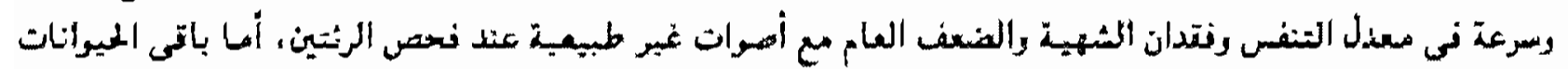

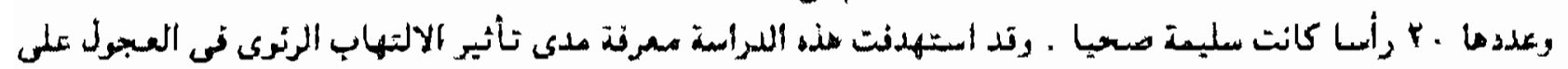

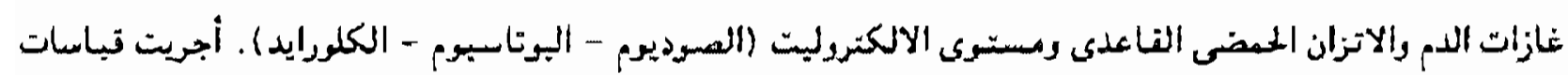

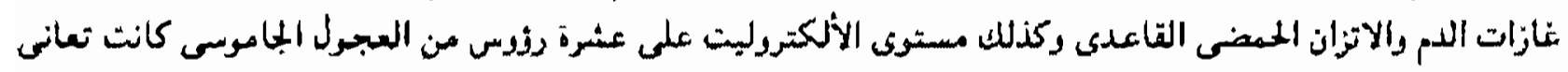

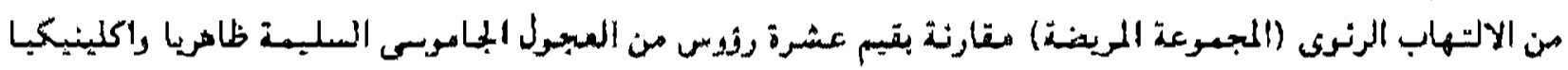

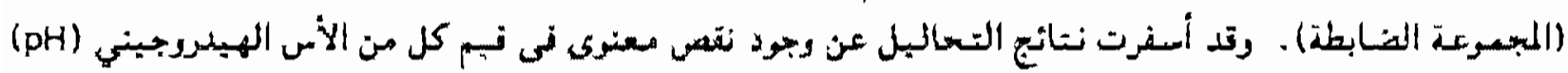

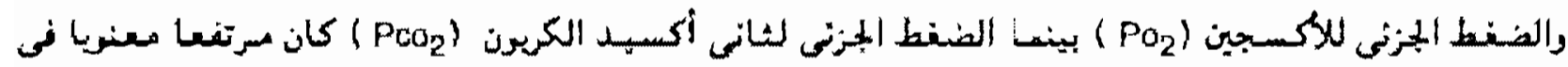

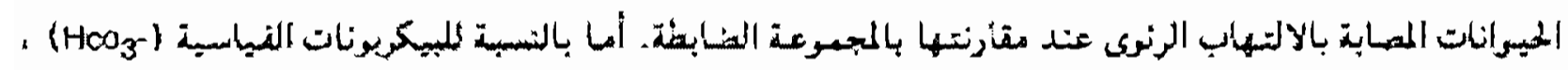

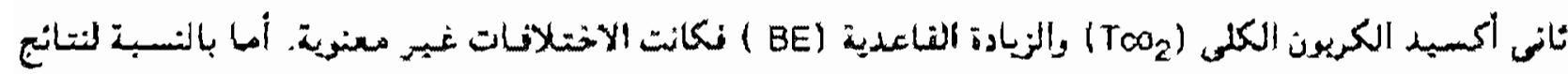

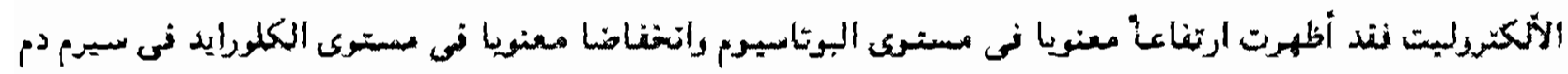

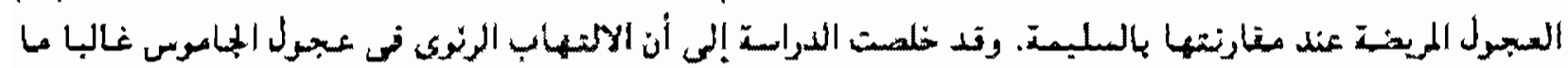

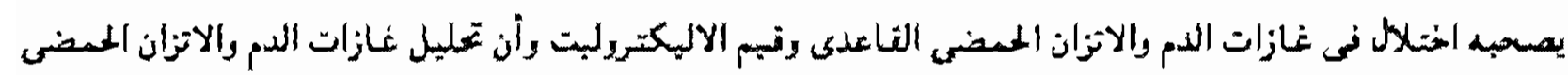

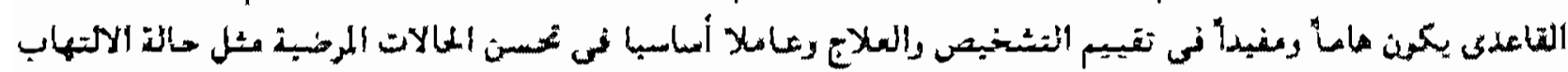
الرتئ نى السيرل 